\title{
373. Zur Differentialdiagnose des Magencarcinoms
}

\author{
H. Bittscheidt, W. Kuhlo, W. Kozuschek, R. Bohnsack und W. Haarmann \\ Chirurgische und Radiologische Universitätsklinik Bochum, Knappschaftskrankenhaus Bochum-Langen- \\ dreer, D-4630 Bochum
}

\section{Observation on Differential Diagnosis of Gastric Cancer}

\begin{abstract}
Summary. About $5 \%$ of tumors of the stomach are neither carcinomas nor sarcomas. A neurinoma occurs in about $1 \%$ of the cases with rare benign and semimalignant tumors. Diseases other than epithelial or systemic disease can be observed in about $3 \%$ of the cases, as for example Hodgkin disease and non-Hodgkin lymphoma. Two of our own cases with non-Hodgkin lymphoma located primarily in the stomach (cardia, gastric stump) are presented. One percent of gastric tumors are regarded as precancerosis, such as Menetrier disease and polyposis. The findings are illustrated and discussed on the basis of our own cases.
\end{abstract}

Key words: Gastric tumors - Hodgkin disease - Non-Hodgkin lymphoma.

Zusammenfassung. In ca. $5 \%$ der Magentumoren handelt es sich nicht um Carcinome oder Sarkome. So finden sich in $1 \%$ der Fälle seltene benigne und semimaligne Tumoren, wie das Neurinom, welches beispielhaft dargestellt wird. In $3 \%$ finden sich nicht epitheliale Malignome und Systemerkrankungen mit Befall des Magens wie z. B. der Morbus Hodgkin und die Non-Hodgkin-Lymphome. Aus dem eigenen Krankengut werden 2 Fälle von Non-Hodgkin-Lymphomen mit primärem Befall des Magens an der Kardia und im Magenstumpf dargestellt. In $1 \%$ der Magentumoren handelt es sich um Praecancerosen wie den Morbus Menetrier und die Magenpolyposis, die ebenfalls an 2 Beispielen kasuistisch dargestellt werden.

Schlïsselwörter: Magentumoren - Morbus Hodgkin - Non-Hodgkin-Lymphom.

\section{Das Magenstumpfearcinom}

\author{
W. Kozuschek, R. Bohnsack, H. Bittscheidt, C. Pelzer und W. Haarmann \\ Chirurgische Universitätsklinik Bochum, Knappschaftskrankenhaus Bochum-Langendreer, D-4630 Bochum
}

\section{Gastric Stump Cancer}

Summary. Gastric stump carcinoma may occur after 5 years or more following surgery of the stomach, with initially benign lesions. Thirty-nine gastric stump carcinomas were operated upon in our clinic between 1975 and 1981. This type of carcinoma develops in stomachs that have been resected by the Billroth II technique (retrocolic anastomosis and short afferent loop). In general, the prognosis is bad. Typical examples are illustrated by pictures of the resected specimen. The stump carcinoma does not exceed the anastomosis. Moreover, the surgical techniques for stomach replacement are presented and discussed with regard to the present possibilities of surgical management.

Key words: Gastric stump - Billroth II - Stomach restoring.

Zusammenfassung. Das Magenstumpfcarcinom ist ein Carcinom in einem wegen eines gutartigen Leiden operierten Magen nach Ablauf von 5 Jahren. Am eigenen Krankengut von 39 Magenstumpfcarcinomen operiert von 1975-1981 wird dargestellt, daß sich das Carcinom bevorzugt nach BII-resezierten Mägen mit retrocolischer Anastomose und kurzer zuführender Schlinge entwickelt, und die Prognose insgesamt schlecht ist. Fallbeispiele mit abgebildeten Operationspräparaten zeigen, daß das Magenstumpfcarcinom die Anastomosenlinie nicht überschreitet. Desweiteren werden Beispiele von Operationstechniken zur Schaffung eines Ersatzmagens bei vorliegender Operabilität vorgestellt.

Schliusselwörter: Magenstumpfcarcinom - Billroth II - Ersatzmagen. 